\title{
Strategi Komunikasi Persuasif dalam Penghimpunan Dana Wakaf di Pondok Pesantren X
}

\section{Ridwan Sadili*}

Prodi Komunikasi Penyiaran Islam, Fakultas Dakwah, Universitas Islam Bandung, Indonesia.

*ridwansadili030997@gmail.com

\begin{abstract}
Communication is an activity that cannot be left by everyone individually or in groups, because with communication a person can convey a message to convey the intent and purpose to the interlocutor. as follows: How does X Islamic Boarding School plan to collect waqf funds through persuasive communication, How is the target of X Islamic Boarding School to collect waqf funds through persuasive communication, What kind of human resources are used by X Islamic Boarding School in collecting waqf funds through persuasive communication, What are the results? the collection of waqf funds for the X Islamic Boarding School with a persuasive communication strategy. The objectives and benefits of this research are, To find out the plan used by X Islamic Boarding School to collect waqf funds through persuasive communication, To find out the target of X Islamic Boarding School to collect waqf funds through persuasive communication, To find out what human resources are used by Baitul Islamic Boarding School Hidayah in collecting waqf funds through persuasive communication, The results of collecting waqf funds at X Islamic Boarding School with persuasive communication strategies. The research method used is a qualitative method of data collection techniques: documentation, observation and interviews. Data analysis techniques used are field observations and interviews. The results of research on persuasive communication strategies in collecting waqf funds at X Islamic Boarding School have good results with a note that there is a lack of special human resources in implementing the targets of collecting waqf funds so far.
\end{abstract}

Keywords: Communication Strategy, Human Resources, Collection Results.

Abstrak. Komunikasi meupakan aktivitas yang tidak bisa di tinggalkan oleh setiap orang secara pribadi atau kelompok, karena dengan komunikasi seseorang dapat menyampiakan pesan untuk memebrikan maksud dantujuan kepada lawan bicara. Dari penelitian yang penulis lakukan pada Penghimpunan wakaf di Pondok Pesantren X, ditemukan latar belakang masalah sebagai berikut: Bagaimana rencana Pesantren menghimpun dana wakaf melalui komunikasi persuasif, Bagaimana target Pesantren menghimpun dana wakaf melalui komunikasi persuasif, Sumber daya manusia seperti apa yang digunakan Pesantren dalam menghimpun dana wakaf melalui komunikasi persuasif, Bagaiamana hasil penghimpunanan dana wakaf Pondok Pesantren X dengan strategi komunikasi persuasif. Tujuan dan manfaat penelitian ini adalah, Untuk mengetahui rencana yang digunakan oleh Pondok Pesantren X menghimpun dana wakaf melalui komunikasi persuasif, Untuk mengetahui target Pondok Pesantren X menghimpun dana wakaf melalui komunikasi persuasif, Untuk mengetahui Sumber daya manusia seperti apa yang digunakan Pondok Pesantren X dalam menghimpun dana wakaf melalui komunikasi persuasif, Hasil penghimpunanan dana wakaf Pondok Pesantren X dengan strategi komunikasi persuasif. Metode penelitian yang digunakan adalah dengan metode kualitatif teknik pengumpulan data: dokumentasi, observasi dan wawancara. Teknik analisa data yang digunakan adalah observasi lapangan dan wawancara. Hasil penelitian terhadap strategi komunikasi persuasif dalam penghimpunan dana wakaf di Pondok Pesantren X memiliki hasil yang baik dengan catatan kendala kurangnya SDM khusus dalam pelaksanaan target dari penghimpunan dana wakaf selama ini.

Kata Kunci: Strategi komunikasi, Sumber Daya Manusia, Hasil Penghimpunan. 


\section{A. Pendahuluan}

Harta merupakan salah satu nikmat Allah yang di berikan kepada manusia sebagai alat yang digunakan untuk memenuhi kebutuhan manusia, dengan harta manusia bisa melakukan transaksi dan komunikasi secara sosial dalam kehidupan, dalam Islam pengaturan harta sangatlah detail di natur dari mulai jenis harta yang dapat dijadikan transaksi sampai kepada teknis pemanfaatan harta semuanya diatur dan dibahas secara detail dan terperinci, mengingat dalam Islam harta termasuk dalam tujuan adanya syariah Islam dalam tatanan hidup muslim.

Potensi wakaf di indonesia sangatlah besar mengingat banyaknya lembaga-lembaga penghimpuanan ziswaf di indonesia yang mengelola dan menghimpundana lewat ziswaf, Jumlah umat islam di Indonesia yang menjadi mayoritas bahkan benjadi penduduk terbanyak di dunia Dalam sebuah laporan yang dirilis oleh Pew Research Center's Forum on Religion \& Public Life pada Januari 2011 disebutkan bahwa dari 1,6 miliyar kaum Muslim di dunia, hampir 62,1\% di antara mereka tinggal di kawasan Asia Pasifik, 19,9\% tinggal Timur Tengah dan Afrika Utara, 15\% menempati wilayah Afrika sub-sahara, 2,7\% di Eropa, dan 0,3\% di Amerika.

Hal ini ditunjukkan melalui data dari Badan Wakaf Indonesia (BWI) (2016) bahwa Indonesia memiliki tanah wakaf seluas 4359443170 meter persegi yang tersebar di 435768 lokasi, namun pemanfaatan tanah wakaf masih terbataspada proyek pembangunan fasilitas ibadah seperti pembangunan masjid sebesar $44.3 \%$ dan mushola sebesar $29.50 \%$.

Dari uraian latar belakang masalah diatas, maka menarik perhatian peneliti untuk mengkaji lebih dalam bagaimana metode dakwah yang dilakukan oleh pondok tersebut melalui skripsi yang berjudul "Strategi Komunikasi Pesuasif dalam Penghimpunan Dana Wakaf di Pondok Pesantren X"

Adapun tujuan dalam penelitian ini adalah:

1. Bagaimana rencana Pondok Pesantren $X$ menghimpun dana wakaf melalui komunikasi persuasif?

2. Bagaimana target Pondok Pesantren $X$ menghimpun dana wakaf melalui komunikasi persuasif?

3. Sumber daya manusia seperti apa yang digunakan Pondok Pesantren $\mathrm{X}$ dalam menghimpun dana wakaf melalui komunikasi persuasif?

4. Bagaiamana hasil penghimpunanan dana wakaf Pondok Pesantren X dengan strategi komunikasi persuasif?

\section{B. Metodologi Penelitian}

Metode penelitian yang digunakan adalah dengan metode kualitatif teknik pengumpulan data: dokumentasi, observasi dan wawancara. Teknik analisa data yang digunakan adalah observasi lapangan dan wawancara.

\section{Hasil Penelitian dan Pembahasan}

\section{Perencanaan Pondok Pesantren X Menghimpun Dana Wakaf Melalui Komunikasi Persuasif}

Dari semenjak Pondok Pesantren $X$ berdiri sebagai pondok wakaf, $X$ tidak pernah memungut biaya pembangunan dan lainnya melainkan seluruh bayaran tahunan dan bulanan santri diberikan kepada santri, maka para pimpinan tidak membahasakan sebagai bayaran santri tapi lebih kepada iuran santri, atau dalam bahasan sunda udunan atau patungan, karena santri mengumpulkan uang semua untuk memenuhi kebutuhan santri-santri lainnya, maka karena dengan iuran santri dari kebutuhan makan,asarama dan buku tahunan semua kembali kepada santri.

Komitmen ini menjadikan kebijakan dari para pimpinan untuk membuat rencana besar berupa membangun beberpa unit Usaha dan membeli beberapa unit kendaraan untuk kebutuhan transpotrasi dan kebutuhan pembangunan. Dari tahun 2010 pertama pesantren berdiri sudah memiliki grand palnning dalam penempatan pembangunan dan sperti apa mestinya penempatan setiap bangunan, yang kala itu baru ada 2 bangunan yang di pakai, asrama Roisi tingkat 1 , dan pada pembuatan grand palnning sudah ada masjid besar dan bebrapa asrama rumah guru, lapangan olahraga dengan segala fasilitasnya. 
Dengan rencana besar itu bagaimana pergerakan pembangunan selalu berjalan panjang, rencana penghimpunan wakaf dengan sistem wakaf dari sebelum ada santri menjadikan $\mathrm{X}$ ingin membuat sistem wakaf yang ada di $X$ tidak mengatasnamakan pondok dalam penghimpunananya melainkan khusus untuk penghimpunan dana diluar sifitas Pondok Pesantren, rencana yang di buat kedepannya bahwa adanya lembaga khusus penghimpunan berbasis wakaf, tidak menjual nama pondok secara langsung.

Dewasa ini $\mathrm{X}$ tidak pernah membuat banner khusus untuk donasi atau membuat media yang disebar untuk kebutuhan pembangunan dan kebuuhan santri, dengan dua komitmen besar yang dimiliki X, Pertama tidak mengambil biaya kepada santri dalam pembangunan, karena dasar pondok dari awal adalah wakaf maka wakaf menjadi dasar pembangunan kedepannya, Kedua tidak pernah menjadikan $\mathrm{X}$ sedang mencari bantuan dari donasi yang si sebar, atau kesannya seperti meminta untuk dibantu kepada publik.

\section{Komunikasi Persuasif X dalam menghimpun wakaf}

Seperti yang di sampaikan oleh Al-Ustadz Iwan sebagai Ketua Yayasan X Nurul Kholish, "Selama ini wakaf yang ada di pondok ada dan terus berjalan dengan komunikasi dari personal kami para pimpinan yang ada dan sepuh sesepuh pesantren yang memiliki relasi, apakah dengan relasi ini X meminta kepada relasi yang ada ? Tentu komitmen untuk tidak meminta-minta tetap di pegang teguh, relasi yang di miliki pimpinan semuanya selalu membaea kabar gembira kepada relasi dengan bercerita dan mohon doa dengan rencana yang ada.

Maka alur penghimpunan yang berjalan selama ini dari personal kami para pimpinan kepada personal relasi yang memang memiliki potensi memberikan amanah wakaf atau memberikan apapun kapada pondok, dari komunikasi personal ini yang dulu membantu 1 juta kemudian komitmen kami menjalin silaturahmi yang baik dan melaporkan kemana donasi yang diberikan secara terbuka, sehingga munculah kepercyaan kepada personal dari para pimpinan dan kepercyaan kepada lembaga".

Dari alur komunikasi dan kepercayaan donatur kepada X mnejadikan donatur yang juga memiliki relalu cukup luas menceritakan apa yang dirasakan oleh donatur kepada relasi yang dimiliki dengan menceritakan kembali, program yang ada di pesantren dan mengajak relasi dari donatur sebelumnya. Maka dalam wawancara Ustadz Iwan menyampaikan "Dari sini kita X menerima bentuk apapun dari wakaf seseorang dan berapapun jumlahnya" maka dari bahasa ini secara tidak lagsung menjadi salah satu cara menarik banyak orang untuk tidak takut, tidak malu untuk membantu $\mathrm{X}$ dengan apapun adanya.

\section{Target Pondok Pesantren X Menghimpun Dana Wakaf Melalui Komunikasi Persuasif}

Dari target pembangunan yang tercatat dalam 3 tahun kebelakang berupa penyelesaian Masjid membangun tingkat 2 gedung Roisy , dan membangun Asrama baru Gontor, dengan targetan ini setiap tahunnya berjalan pembanguna, dari seluruh bangunan sudah bisa dignakan dengan adanya belum sempurna pembangunannya, karena dalam pesantren kita tidak menunggu sempurna untuk memulai tapi mulai untuk kesempuraan. Dari hasil wawancara penulis dengan Ketua Yayasan dapatlah data target yang dicanangkan untuk pembangunan 3 bagian gedung yang ada di pesantren dengan rancangan anggaran pembangunan yang telah di rumuskan yang kepada yang ahli dalam rencana 3 aset pesantren yang akan di bangun.

Adapun alur sosialisi yang ada selama ini masih seperti yang di jelaskan dalam komunikasi perencanaan, dengan komunikasi yang sebaik mungkin menjaga kepercayaan dengan selalu mealporkan apa yang telah di berikan, bahkan dalam beberapa momen besar pondok para donatur ini di undang sebagai salah satu cara menjalin komunikasi dan silaturahmi yang baik, dalam moment undangan tersebut di ajak dan dijelaskan kepada para donatur bahwa dana yang sebelumnya diberikan telah jadi ini itu dan sebaginya, bahkan tidak sedikit dari kunjungan juga para donatur mendatangkan teman-temanya untuk hadir dan ikut menyaksikan kegitan santri dan berkeliling melihat keadaan pondok. 
Dalam perencanaan yang telah di rancang salah satuya adalah memiliki lembaga khusus yang mengurusi penghimpunan wakaf, dari tahun 2010 sampai 2013 keutuhan pondok masih banyak di bantu oleh pewakif dan beberapa donatur yang di bawa oleh pewakif, dengan keadaan ini pimpinan ingin lebih mandiri dari segi finansial dengan memulai membuka unit usaha milik pesantren dengan skala kebutuhan santri.

Maka pada tahun 2014 rencana pembentukan tim khusus untuk penghimpunan wakaf mulai menemui titik terang, yaitu adanya beberapa orang yang igin berkontribusi untuk menjadi tim khusus dalam penghimpuanan dan penggalangan, dan yang datang untuk kontribusi dalam penghimpunan adalah orang yang mumpuni dalam bidangnya, dari tim khusus berikut ada 4 orang yang terlibat menjadi tim khusus penghimpunan. Dan telah masuk kepada struktur dalam bahasan rencana.

\section{Kesimpulan}

Rencana Pengimpunan dana Wakaf di Pondok Pesantren X melalui komunikasi persuasif belum terlaksana dengan baik karena dalam proses perencanaan belum sesuai dengan terori manaejmen dalam perencanaannya, Target pengimpunan dana komunikasi persuasif belum bisa dikatakan berhasil karena dari tolak ukur hasil yang belum tercapai, selain itu target yang di bangun dalam penghimpunan belum menyeluruh. selama 10 tahun perjalanan pesantren dengan sistim wakaf belum bisa membentuk tim khusus dengan komitmen menjalankan tuganya, karena masih mengandalkan relasi dari para pimpinan.

Hasil Pengimpunan dana belum tercapai sesuai target, sehingga dari 3 tahun data terakhir penghimpunan wakaf belum satupun sampai pada target yang telah di buat, maka membuktikan bahwa belum maksimalnya penghimpunan wakaf di X.

\section{Acknowledge}

Berisi ucapan terima kasih kepada pihak-pihak terkait yang membantu penelitian Anda.

\section{Daftar Pustaka}

Buku:

[1] Ahmad Sarwat Lc. MA, Fiqih Waqaf : Mengelola Pahala Yang Tidak Berhenti Mengalir [Book]. - Jakarta Selatan : Rumah Fiqih Publishing, 2018 . - Vol. 1.

[2] Ahmadi Rulam Metodologi Penelitian Kualitatif [Book]. - Yogyakarta : [s.n.], 2016,.

[3] Bungin Burhan Penelitian Kualitatif Komunikasi, Ekonomi, Kebijakan Publik, dan Ilmu Sosial Lainnya [Book]. - Jakarta : Prenada Media Group, 2006. - Vols. Ed. Ke-2.

[4] Emzir Metodologi Penelitian Analisi Data [Book]. - Jakarta : PT. Raja Grafindo Persada,, 2012. - Vol. 1.

[5] Peterson William. L. Rivers dan Jay W. Jensen Theodore Media Massa dan Masyarakat Modern [Book]. - Jakarta : Prenada Media Group, 2003.

[6] Ruslan Rosady Kiat dan Strategi Kampanye Public Relations [Book]. - Jakarta : Grafindo Persada, 2000.

[7] Sadiah Dewi Metode Penelitian Dakwah Pendekatan Kualitatif dan Kuantitatif [Book]. Bandung : PT. Remaja Rosdakarya, 2015. - Vol. 1.

[8] Yusuf A. Muri Metodologi Penelitian Kuantitatif dan Penelitian Gabungan [Book]. Jakarta : PT. Prenada Media Group, , 2014.

\section{Jurnal/Skripsi:}

[1] Anaomi Strategi Komunikasi Persuasif Human Resources Development Dalam Menyelesaikan Konflik Karyawan Pt. Dimas Drillindo Cabang Provinsi” [Journal]. - Duri : Jom FISIP, 2017. - Jurnal : Vol. Vo. 4 No.2.

[2] Ardiansyah Fikri Strategi Penghimpunan Dan Wakaf Tunai Di Masjidtaqwa Magelangan Ganjar Asri Metro Barat, [Journal]. - Magelangan : (Jurusan Perbankan Syari'Ah Fakultas Ekonomi Dan Bisnis Islam Institut Agama Islam Negeri (IAIN) Metro),, 2018. - Skripsi. 
[3] Astuti Riyandari Strategi Komunikasi Pembangunan Dalam Mempertahankan Pasar Tradisional Sentral Benteng Di Kabupaten Kepulauan [Journal]. - Selayar : (Jurusan Ilmu Komunikasi Pada Fakultas Dakwah Dan Komunikasi UIN Alauddin Makassar, 2017. Skripsi.

[4] Hasim K Lubis L, Ali KM Analisis Faktor Yang Mempengaruhi Penghimpunan Wakaf Uang [Journal]. - Jakarta : Neliti, 2016. - Penghimpunan Wakaf Uang: Vols. Vol.4, No.2.

[5] Hayat Bahrul Kontribusi Islam Terhadap Masa Depan Peradaban di Asia Tenggara" [Journal]. - Jakarta : MIQOT, 2012. - Vol. XXXVI.

[6] Megawati Wahyuni Strategi Komunikasi Persuasif Komunitas Rumah Belajar Ceria Dalam Program Pemberdayaan Masyarakat di Kampung Sungai Pedado [Journal]. - Palembang : (Jurusan Imu Dakwah Dan Komunikasi Program Studi Komunikasi dan Penyiaran Islam UIN Raden Fatah, 2018. - Skripsi.

[7] Pertiwi Dian Strategi Komunikasi Persuasif Dalam Meningkatkan Jumlah Debitur Di PT.BNI (Persero) Tbk Kantor Cabang [Journal]. - Padang, : [s.n.], 2019),. - Skripsi..

[8] Suhendi Hendi Strategi Peninkatan Penghimpunan Wakaf Emlalui Kegiatan Dakwah [Journal]. - Bandung : Spesia, 2020. - Vol. 1.

\section{Internet:}

[1] Intan Ghita Potensi wakaf di Indonesia [Article]. - JAKARTA : https://www.voaindonesia.com, 2021. - 25/01/2021. - Potensi Wakaf : Vol. 5750571.

[2] Imam Bawani, Tradisionalisme Dalam Pendidikan Islam, (Surabaya: Al-Ikhlas), 5, Skripsi Farid Bagus Bab 2, hlm 1 dalam http://etheses.iainkediri.ac.id/509/3/5_BAB\%202_FARID\%20BAGUS\%20W_931 305212.pdf .-diunduh 10/8/2021 pukul 09:25.

[3] Ira Muniratul Ulfah, Op. Cit, hlm. 16, https://sc.syekhnurjati.ac.id/esscamp/risetmhs/BAB21414311006.pdf. -diunduh 10/8/2021 pukul 10:00.

[4] Haidar Putra Daulay, Op. Cit, hlm. 183, https://sc.syekhnurjati.ac.id/esscamp/risetmhs/BAB21414311006.pdf. -diunduh 10/8/2021 pukul 10:01.

[5] Jasmadi, Moderenisasi Pesantren, (Jakarta: Ciputat Press, 2002), h. 7014 M. Bahari Ghazali, op.cit, h. 50-51 22 kitab-kitab Islam. http/ BAB2 1414311006\%20PESANTREN.pdf diunduh 10/8/2021 pukul 10:01.

[6] Imam Bawani, Tradisionalisme dalam Pendidikan Islam Studi Tentang Dayatahan Pesantren Tradisional, (Surabaya: Al-Ikhlas, 1993), hlm. 95, dalam BAB2 1414311006\%20PESANTREN.pdf diunduh 10:22

[7] Masjkur Anhari, Integritas Sekolah ke Dalam Sistem Pendidikan Pesantren, (Surabaya: Diantama, 2017), Cet. Ke-1, hlm. 19-20

Profil Pondok Pesantren Xhttp://ppikpm.gontor.ac.id > dhvcform > 2019/07, dalam doc word di Unduh 10/08/2021 